$\begin{array}{ll} & \text { Etnográfica } \\ \text { etnográfica } & \text { Revista do Centro em Rede de Investigação em }\end{array}$

Antropologia

vol. $12(1) \mid 2008$

Vol. $12(1)$

\title{
Língua, nome e identidade numa situação de plurilinguismo concorrencial: o caso de Timor- Leste
}

Language, name and identity in competitive plurilingualism: the case of East-

Timor

\section{Rui Graça Feijó}

\section{(2) OpenEdition}

\section{Journals}

\section{Edição electrónica}

URL: https://journals.openedition.org/etnografica/1641

DOI: 10.4000/etnografica.1641

ISSN: 2182-2891

\section{Editora}

Centro em Rede de Investigação em Antropologia

\section{Edição impressa}

Data de publição: 1 maio 2008

Paginação: 143-172

ISSN: 0873-6561

\section{Refêrencia eletrónica}

Rui Graça Feijó, «Língua, nome e identidade numa situação de plurilinguismo concorrencial: o caso de Timor-Leste», Etnográfica [Online], vol. 12 (1) | 2008, posto online no dia 20 junho 2012, consultado o

11 fevereiro 2022. URL: http://journals.openedition.org/etnografica/1641 ; DOI: https://doi.org/

10.4000/etnografica.1641

\section{(c) (†) 8}

Etnográfica is licensed under a Creative Commons Attribution-NonCommercial 4.0 International License. 


\section{Língua, nome e identidade numa situação de plurilinguismo concorrencial: o caso de Timor-Leste ${ }^{1}$}

\section{Rui Graça Feijó}

Este ensaio debate as relações entre língua, nome e identidade no contexto plurilinguístico de Timor-Leste. Mais concretamente, aborda a questão da relação entre o nome próprio e o nome de família como uma das singularidades do sistema linguístico timorense. Através dos nomes e das práticas de nomeação em Timor-Leste e da forma como se constroem e se articulam com outros fenómenos coevos, pretendo chegar à discussão dos níveis de identidade cultural e das bases sobre as quais assenta o próprio sentimento de identidade nacional timorense.

PALAVRAS-CHAVE: Timor-Leste, nomeação, plurilinguismo concorrencial, identidade.

$\begin{array}{lll}\text { Para } & \text { Aida } & \text { Reka } \\ \text { Ana } & \text { Rosa } \\ \text { Anita } & \text { Tina } \\ \text { Anona } & \\ \text { Beba } & \text { que em Dili me encheram } \\ \text { Guio } & \text { de mimos, iguarias e conversas. }\end{array}$

l Texto preparado para o simpósio internacional Nomes e Pessoas: Género, Classe e Etnicidade na Complexidade Identitária" realizado no ICS (2006). Agradeço à Comissão Organizadora, e sobretudo a João de Pina Cabral, o convite para participar. A investigação corporizada neste artigo foi integralmente suportada pelo autor, sem recurso a entidades públicas ou privadas. 


\author{
Meu nome é a minha voz \\ dirigida ao pensamento \\ Ruy Cinatti \\ O fio de Ariadne que conduz o investigador no labirinto \\ é aquilo que distingue um indivíduo de outro \\ em todas as sociedades conhecidas: \\ o nome. \\ As linhas que convergem para o nome e que dele partem, \\ compondo uma espécie de teia de malha fina, \\ dão ao observador a imagem gráfica \\ do tecido social em que o indivíduo está inserido \\ Carlo Ginzburg
}

AS EPÍGRAFES ESCOLHIDAS PARA ESTE ENSAIO BALIZAM O TEMA DESTE colóquio entre a evocação poética e a análise sociológica e revelam, pela amplitude da diferença entres estes dois registos, a vastidão dos campos em que os nomes de pessoas ganham sentido e significado. Se a convocação de Ruy Cinatti poderia ser justificada pela sua profunda ligação a Timor, que bem conheceu e onde residiu vários anos, mais sentido tem verificar o alcance da sua referência, nesse contexto, à questão do nome.

A prática de nomeação assume, como fortemente sublinha Carlo Ginzburg, uma feição de mecanismo universal de referência social, no qual convergem duas funções diferenciadas: a identificação através da individuação de cada elemento no conjunto do grupo alargado (entre nós, através daquilo que designamos "nome próprio"); e a vinculação desse mesmo elemento a um grupo social mais restrito, que identificamos com os seus parentes (através da partilha de "nomes de família").

Estes pressupostos mais não fazem do que sublinhar a pertinência de convocar as práticas de nomeação pessoal, como práticas universais e portanto eminentemente comparáveis, para através delas - e sobretudo das modulações e das variações que apresentam - aceder a elementos fundamentais das estruturas socioculturais dos ambientes em que são produzidas. Usemos, pois, os nomes para ver Timor para além deles.

Este jovem país satisfaz a condição empírica básica que preside a este volume em que se foca "em especial os nomes de pessoa tal como usados em contexto social onde o português é a língua de referência” (Pina Cabral e 
Viegas, 2007: 13). Neste universo linguístico-geográfico, prestaremos particular atenção à forma como se convoca o guarda-chuva da língua portuguesa para abrigar um mundo particularmente rico e aberto de vocábulos, ou seja, os nomes que os timorenses usam "como se fossem nomes portugueses" (idem: 15), evidenciando uma criatividade no emprego da língua que desafia as definições administrativo-burocráticas das instituições formais de controle dos nomes portugueses. Esta criatividade é interpretada no contexto de isolamento cultural e da vontade política de opor a língua portuguesa, oficialmente banida no território, à predominância da nova língua indonésia que acompanhava a ocupação do território após 1975.

Este ensaio remete para uma discussão sobre a existência de acervos abertos ou fechados de nomes como um dos pilares possíveis do nosso debate - como referiu Manuela Carneiro da Cunha durante o nosso simpósio. Mais ainda, a questão da relação entre o nome próprio e o nome de família (as regras de composição do nome completo) merecerá especial atenção, já que com toda a evidência se trata de uma das singularidades do sistema timorense tal como se configurou no período estudado. Através dos nomes e das práticas de nomeação em Timor-Leste e da forma como se constroem e se articulam com outros fenómenos coevos, pretendo chegar à discussão dos níveis de identidade cultural e das bases sobre as quais assenta o próprio sentimento de identidade nacional timorense.

\section{TIMOR-LESTE : UM CASO DE PLURILINGUISMO CONCORRENCIAL}

\section{1. (traços da relação entre Timor e Portugal)}

Timor Lorosa'e - a Republica Democrática de Timor-Leste - é o mais jovem Estado do Mundo. A proclamação da sua independência ocorreu em 20 de Maio de 2002, após um período de dois anos e meio em que o território foi administrado pelas Nações Unidas. A opção pela independência fora assumida no referendo de 30 de Agosto de 1999, quando quase quatro em cada cinco eleitores recenseados recusaram uma proposta que previa a concessão de autonomia administrativa no quadro da República Indonésia. ${ }^{2}$ Oficialmente, porém, trata-se da Restauração da Independência proclamada em 1975. A Indonésia reagira a essa declaração e ocupara militarmente Díli e o então Timor Português - território não-autónomo sob administração portuguesa, como o considerava a ONU - a 7 de Dezembro de 1975, e incorporara pela via das armas esse território nas suas fronteiras, vindo a consagrar mais tarde essa anexação com a criação da sua 27. ${ }^{a}$ Província - Timor Timur (TimTim). Essa incorporação 
nunca foi plenamente sancionada pela comunidade internacional, sendo o seu reconhecimento recusado pelas Nações Unidas.

A relação de Timor com Portugal remonta ao início do século XVI. Gama entra no Índico em 1498 e logo chega a Cochim, no sul da Índia, com a preciosa ajuda dos pilotos postos ao seu dispor pelo rei de Melinde, conforme nos conta Camões (Lusíadas, Canto VI). Na verdade, o Oceano Índico era, pelo menos desde o século XII, um espaço profusamente navegado, e não espanta que Afonso de Albuquerque tenha chegado em 1511 à conquista de Malaca - importante entreposto na zona oriental desse oceano -, donde os portugueses seguiriam poucos anos mais tarde nas rotas conhecidas até uma ilha afamada pelo seu sândalo. ${ }^{3}$ Se de Ceuta (1415) ao Cabo (1488) pelo Atlântico "nunca dantes navegado" decorreram mais de setenta anos, dobrado o Cabo e atingido, por sul, o extremo das rotas comerciais e de navegação regulares, os europeus chegariam ao outro extremo do Índico em menos de vinte anos.

São conhecidas as vicissitudes do Império Português no Oriente (Subramahnyam 1995), em que Timor ocupava um remoto e distante lugar apenas de comércio. Nos séculos iniciais da sua presença, os interesses portugueses "ainda além da Taprobana" (Ceilão) concentravam-se em Malaca, na rota das Molucas e, para norte, em Macau, donde atingiam o Japão. A procura do sândalo - produto que singularizava Timor - e a oferta de bens de troca para este afamado produto situavam-se ambas no contexto das rotas comerciais do Extremo-Oriente, e pouco contribuíam directamente para a articulação Ásia-Europa em que os portugueses maioritariamente se especializavam.

Até ao dealbar do século XVIII, a "administração" de Timor foi efectuada a partir de outros pontos. Os governadores portugueses não exerciam sobre esta ilha um controle territorial directo nem autónomo, antes incluindo Timor no conjunto das possessões das Sundas Menores (Solor e Flores). Só em 1702 passou Timor a ser administrado por um governador residente em Lifau - onde ainda em finais de seiscentos Dampier encontrara apenas três portugueses, dois dos quais religiosos. ${ }^{4}$ A saga do estabelecimento da administração política directa haveria de marcar o século XVIII, pelo menos até à transferência da sede para Díli em 1769 (Gunn 1999: 78-81).

Em meados do século XIX, em plena segunda vaga de colonização europeia do Sudeste Asiático, Portugal assina com a Holanda, potência colonizadora da grande Batavia e das Índias Orientais, um tratado de delimitação de fronteiras na ilha de Timor (1859) - fronteiras essas que correspondiam, grosso modo, a uma divisão interna da ilha em dois "reinos", um dos quais (o dos Belos) estabelecera relações com Portugal, e que este geria através do fomento de jogos de alianças e rivalidades envolvendo as autoridades locais tradicionais. Essas 
fronteiras viriam a ser ligeiramente alteradas até 1915, ano em que uma sentença arbitral as consolidou, ${ }^{5}$ perdendo Portugal os enclaves na zona ocidental da ilha, com excepção de Oecussi (que correspondia a um reino que resistia ao calvinismo), e acabam de ser recuperadas, em termos gerais, pelo novo Estado independente. ${ }^{6}$

A divisão da ilha em dois "reinos", porém, carece de um adequado enquadramento. A natureza de um (política) e de outro (espiritual ou moral) não seria idêntica, e a complementaridade entre eles parece ter sido mais importante que a oposição mais frequentemente mencionada. A territorialidade de um e de outro também deve ser entendida em sentidos distintos, pelo que é da mais prudente cautela não assumir uma simetria entre ambos os reinos e nela basear a força de uma explicação. ${ }^{7}$

Por alturas desse tratado, o saboroso comentário de Eça de Queirós a propósito das possessões portuguesas do Oriente ("Elas não nos dão rendimento algum: nós não lhes damos um único melhoramento; é uma sublime luta - de abstenção» - Eça de Queirós, s.d. [1890]: 1028) poderia certamente aplicar-se com propriedade a Timor. Mas, na viragem do século, a colonização portuguesa assume uma nova forma com as campanhas levadas a cabo pelo governador Celestino da Silva (1894-1908), abandonando-se a forma de "protectorado" de diferentes reinos para impor uma presença militar portuguesa, bem como fomentar o estabelecimento de colonos europeus. A famosa revolta de Manufahi (1912) parece ter marcado um ponto de viragem na história deste território. Só então a presença de portugueses - de falantes de língua portuguesa - começou a fazer sentido mais que residual no território. Ainda em finais de oitocentos Leite de Vasconcellos inclui o falar português de Timor entre os muitos que se espalhavam pela Ásia, sem lhe dar especial relevo. ${ }^{8}$ Mesmo em face desse novo impulso, um administrador colonial na década de 1930 distingue Timor das outras possessões coloniais portuguesas (que conheceria em primeira mão) por ser "uma colónia sem colonos" (Correia 1944: 15). A acção desenvolvimentista do novo colonialismo foi, nestas terras longínquas,

5 Vide de Roever (1998) para uma interpretação distinta do quadro em que ocorreu a partilha de Timor.

6 Como muito bem nota Mattoso (2005b: 11), a delimitação colonial de fronteiras seguiu frequentemente critérios que "nem sempre correspondiam a fronteiras étnicas". O caso da ilha de Timor pode ser dado como exemplo, uma vez que as fronteiras políticas não têm correspondência na realidade sociolinguística. Formas de tétum são comuns aos dois territórios, ocidental e oriental.

7 No século XVII, os governantes do Vietname e do Laos resolveram um conflito fronteiriço no vale do Mekong, concordando em que os habitantes dessa região cujas casas assentavam em estacas ficavam sujeitos à soberania da monarquia laociana, enquanto aqueles cujas casas tinham chão térreo obedeceriam aos governantes vietnamitas (Owen 2005: 10). Este exemplo evidencia com clareza que, no Sudeste Asiático, a noção de Estado-nação vigente na Europa estava muito longe de constituir um modelo de organização política territorial.

8 Leite de Vasconcellos citado em Buescu (1983: 88). 
pouco mais que simbólica: em 1915, criam-se as primeiras escolas primárias e, em 1938, um liceu em Díli. Nos anos 30, em toda a circunscrição dependente de Baucau (quase metade do Timor português) havia seis escolas primárias...

As ordens religiosas, instaladas no território desde 1633, parece terem feito um pouco mais. Como sublinha Kohen, a Igreja Católica tinha uma presença muito mais alargada e com maior credibilidade junto das populações de Timor-Leste do que a administração colonial (2001: 46), embora não seja seguro se a sua presença seja equivalente a uma presença forte da língua portuguesa, que é o aspecto particular que aqui nos importa. Em 1898, os jesuítas fundaram um seminário em Soibada (distrito de Manatuto) e, mais tarde, um colégio em Dare (arredores de Díli). Esses terão constituído o berço de formação da elite timorense até $1975 .{ }^{9}$

Os três primeiros quartéis do século XX terão sido o momento em que a língua portuguesa assumiu o carácter de questão relevante na sociedade timorense, muito mais pela sua articulação com a elite local do que pela força da sua expressão numérica, que todos os autores consideram ter sido fraca. As estatísticas oficiais comentadas por Thomaz (1994: 672-673) apontam, nas vésperas do 25 de Abril de 1974, para um total de 1200 europeus, dos quais três quartos pelo menos seriam militares (em comissão de serviço de curta duração) ou elementos das forças policiais, e apenas três centenas seriam colonos - distribuídos entre a administração, a prestação de serviços e uma rudimentar presença no sector primário - efectivamente radicados no território. Parcos recursos para que a língua portuguesa pudesse ter uma importância além de círculos restritos da elite local.

\section{2. (panorama linguístico de Timor)}

Babel Loro Sa'e - este é o sugestivo nome de uma colecção de ensaios de um dos mais credenciados conhecedores da história e da cultura timorenses, Luís Filipe Thomaz (2002). De facto, o mapa linguístico de Timor-Leste compreende dezasseis línguas autóctones, inseridas em duas grandes phyla - quatro de origem papua, e doze de origem austronésia. ${ }^{10}$ Esta extrema fragmentação linguística favoreceu o aparecimento de línguas de contacto (língua franca), capazes de facilitar contactos e proporcionar inteligibilidade nas relações entre os

9 No domínio da ficção literária, mas num registo próximo do memorialismo, Crónica de uma Travessia, do romancista timorense Luís Cardoso, apresenta um retrato dessa última geração da elite portuguesa, em parte a elite da independência. Nele se evidencia a importância de Soibada e de Dare. Vide também Kohen (2001: 46).

10 Seguem-se aqui os ensinamentos de Geoffrey Hull, que classifica como sendo de origem austronésia as seguintes línguas: tétum, habun, kawaimina, galoli, wetar, bekais, dawan, mambai, kemak, tokodede, lovain - sendo que o wetar de Ataúro, a pequena ilha situada defronte a Díli tem, nesse território de 140 quilómetros quadrados, menos de oito mil habitantes e seis povoações, mas diferencia-se em três dialectos distintos. As quatro línguas papuas são o makasai, makalero, bunak e fataluku. 
diversos grupos de falantes. Em Timor-Leste, essa função foi desempenhada, ao longo do último século, pelo tétum-Praça (ou tétum-Díli), uma forma específica do tétum, crioulizado pelo português.

É necessário considerar que, além deste mosaico linguístico autóctone, outras línguas se falam igualmente no território. A língua inglesa acompanhou a deslocação da ONU e da comunidade de "internacionais" estacionados no território após o referendo de 1999, e tem um estatuto particular. Uma outra está praticamente confinada à minoria chinesa. Outras duas, porém, assumem uma importância fulcral no panorama linguístico e cultural da jovem nação: o português e o bahasa indonésio. ${ }^{11}$

Até finais do século XIX, formas crioulas de malaio - antepassados da língua padronizada que hoje se designa por bahasa indonésio ${ }^{12}$ - falavam-se ao longo de toda a costa desta ilha, sobretudo como forma de facilitar os contactos com visitantes de fora. $\mathrm{O}$ seu uso na parte leste da ilha foi decaindo com o aumento da presença da administração portuguesa, sendo o seu uso praticamente residual em 1975 (Thomaz 1994: 616). Após a invasão militar indonésia, porém, o bahasa indonésio tornou-se língua oficial do território - a língua da administração pública e do ensino, da polícia e do exército. As gerações que foram à escola no período entre 1975 e 1999 - e mesmo depois... - fizeram a sua aprendizagem básica nessa língua, assim como os estudantes que contestaram o regime de Suharto, os timorenses que procuraram emprego na administração pública ou que se quiseram dirigir ao hospital para consultar um médico. Em termos gerais, pode-se afirmar que, à medida que os níveis de instrução da população iam crescendo e os serviços sociais públicos iam estendendo os seus ramos (que, por muito débeis que fossem, representavam uma modificação positiva relativamente ao "tempo dos portugueses"), o bahasa indonésio ia-se espalhando e assumindo um papel cada vez mais importante na intercomunicação entre os timorenses.

Quando, em 1975, a língua portuguesa foi proibida era falada pela pequena comunidade de mil e duzentos europeus e por alguns timorenses, sobretudo a elite local que frequentava as escolas primárias e secundárias, ${ }^{13}$ ocupava alguns cargos administrativos, ou que havia sido recrutada pelas forças armadas portuguesas. ${ }^{14}$

A Igreja Católica era uma das instituições que mais se apoiava na língua portuguesa. As reformas que aboliram o latim como língua de culto, primeiro,

11 O termo "bahasa" designa, num significativo número de línguas do Sudeste Asiático, "língua"; pelo que se deve sempre acompanhar da língua específica a que nos queremos referir.

12 Sobre a história desta língua, vide Owen (2005).

13 Os muito raros timorenses que frequentaram escolas de ensino pós-secundário fizeram-no em Macau, nas colónias portuguesas de África ou mesmo no "continente".

14 É ainda elevado o número de timorenses com mais de 50 anos que fala um português aprendido na tropa... 
e a proibição do português pelos indonésios, depois de 1975, porém, levaram-na nos anos 80 a voltar-se para o tétum-praça como língua litúrgica. ${ }^{15}$ Deste modo pôde escapar, em grande medida, ao fenómeno da imposição do bahasa indonésio como "nova" língua do território. Apenas em Díli, e numa só igreja - Santo António de Lisboa de Motael - a nova administração tolerava uma missa semanal em língua portuguesa, de resto proibida pelos indonésios em todo o culto católico público. São de realçar os esforços do actual bispo de Díli, D. Alberto Ricardo da Silva, na produção de versões em tétum de textos religiosos. ${ }^{16}$ Tive ocasião de ouvir algumas pessoas referir o contraste existente entre o clero católico de 1940, que se exprimia em português, e o clero pós-1975, que se exprimia nas línguas autóctones e praticava uma liturgia em tétum, como um factor explicativo do contraste entre o sucesso deste último e a relativa irrelevância do primeiro, com uma geração de intervalo.

Não admira, pois, que a jovem república tenha optado por inscrever na sua constituição política duas línguas com o estatuto de língua oficial do país ${ }^{17}$ - o tétum-praça, língua efectivamente falada por um significativo número de pessoas, mas que nenhuma fonte considera ter um efectivo poder de operar em todo o território timorense, ${ }^{18}$ e o português, língua com ampla expressão junto das elites políticas que sustentam o processo de independência e com objectivos estratégicos de afirmação cultural própria ${ }^{19}$. - a par de duas que, mercê de circunstâncias históricas, foram consideradas como "línguas de trabalho" - o inglês ${ }^{20}$ e o bahasa indonésio.

15 O Ordinário da Missa foi traduzido em 1980. "A Igreja tornou-se a muralha da integridade cultural, que, com a tradução de vários textos sagrados beneficiou o estatuto do tétum-Díli, impregnando-o das variedades terik e belu, o que resultou numa variedade literária daquela língua crioulizada" (Carvalho 2002a: 69).

16 Veja-se o testemunho do padre Leão da Costa quanto à determinação das autoridades indonésias de "varrer do ensino tudo o que tivesse sabor a português" e à responsabilidade do clero na divulgação do tétum como língua de culto (com "superior aprovação da Santa Sé”) - cf. Costa (2003: 16-17).

17 Constituição da República Democrática de Timor-Leste, artigos n. ${ }^{\circ} 13$ (Línguas Oficiais) e n. ${ }^{\circ} 159$ (Línguas de Trabalho).

18 O tétum-praça tem sido alvo de atenção por parte das autoridades políticas da RDTL que, em 2004, adoptaram legislação com o intuito de fixar as regras básicas desta língua. Deve-se salientar que é falsa a ideia de que o tétum-praça é falado em todo o território da jovem nação. Na ponta leste, por exemplo, onde domina o fataluku, dificilmente se ouve falar tétum-praça, sendo a segunda língua (sobretudo na geração mais velha) muitas vezes o português. As opções políticas em torno da língua não se esgotam neste apontamento, mas trata-se de uma polémica que não cabe aqui desenvolver.

19 Segundo a UNTAET (citada em Carvalho 2001) a percentagem de timorenses que falavam português em 1999 seria da ordem dos $11 \%$.

20 O convívio directo com a "comunidade internacional de Díli leva-me a considerar que o o caracter de língua franca atribuído ao inglês se revela com muito maior facilidade e poder comunicacional na palavra escrita que na palavra falada - onde o problema da pronúncia (imagine-se um colombiano a falar inglês com um marfinense, ou um indiano com um francês...) é efectivamentre muito elevado. Opinião contrária parece ter Vaclav Havel, antigo Presidente da República Checa, que terá afirmado o seguinte: de uma conversa em inglês entre um checo e um brasileiro, ou entre um [continua] 
De uma forma muito vincada, as línguas de cultura oriundas do exterior do território associaram-se no século XX a projectos políticos, nenhum dos quais de cariz democrático, e assumiram uma feição coerciva - certamente mais o bahasa indonésio que o português. De facto, o programa de integração e desenvolvimento desenhado pelo governo de Suharto baseava-se na ideologia designada "Panca Sila" que se revelava tolerante do ponto de vista da religião - permitindo que os indivíduos escolhessem uma de entre as religiões aprovadas pelo Estado (Owen 2005: 445) - mas particularmente intolerante no que concerne à língua.

O modo como as línguas foram apropriadas, manipuladas e usadas pela população local para prosseguir fins próprios, porém, ultrapassa em muito uma história que se centra nas relações verticais, de cima para baixo, entre colonizadores e ocupantes, por um lado, e a população timorense, por outro. A história do século XXI começa - com toda a força da evidência que não passa desapercebida a quem contacta com o território - de uma forma significativamente diversa

\section{3. (sobre língua e identidade)}

Timor-Leste é um país onde a maioria da população é bilingue ou mesmo plurilingue, ${ }^{21}$ e onde a escolha da(s) língua(s) que cada um fala e em que se exprime socialmente assume uma importância capital no processo de identidade colectiva. Na verdade, a relação que se estabelece entre as várias línguas é, ela própria, plurifacetada: se o tétum-praça tende a ser uma língua veicular complementar das demais línguas autóctones (e é geralmente entendido como uma segunda língua usada para contactar falantes de outras línguas, não suscitando formas de concorrência, de rivalidade, de antagonismo), ${ }^{22}$ o mesmo não se poderá afirmar das outras línguas em jogo. A opção pelo bahasa indonésio ou pelo português tende a ser mutuamente exclusiva, ou seja: quem opta por se exprimir em bahasa indonésio neste contexto plurilinguístico fá-lo em oposição, em contraponto, a uma opção alternativa que seria a expressão em língua portuguesa. ${ }^{23}$

Não espanta que as novas autoridades timorenses se tenham apressado a fixar um quadro legal que, reconhecendo a necessidade de estabelecer um período de transição para uma nova paisagem linguística e de integrar a totalidade da

espanhol e um húngaro, perceberia 100\%; de uma conversa entre norte-americanos, compreenderia $50 \%$; e de uma conversa entre dois ingleses, perceberia nada (citado em Garton Ash, 2004).

21 Thomaz (2002: 167).

22 Esta generalização poderá ser excessiva no caso de zonas como a Ponta Leste dos Fatalukus, onde o tétum suscita reacções por vezes mais negativas que o português.

23 Muito embora se encontrem pessoas capazes de se exprimirem simultaneamente em português e em bahasa indonésio, é frequente que escolham uma destas línguas e ocultem (socialmente) o domínio que têm da outra. 
comunidade timorense na nova nação, acarinha a reemergência do português como um factor de diferenciação no contexto geopolítico local - tanto em relação ao passado recente de anexação pela Indonésia, como no plano mais vasto da predominância do inglês nesta zona do globo. Importa, no entanto, dar um passo atrás, indagando até que ponto esta conflitualidade estava já presente na sociedade timorense antes do Referendo de 1999, e que significado the poderemos atribuir. Na busca de uma resposta a estas preocupações, vamos centrar a nossa atenção sobre nomes.

$\mathrm{Na}$ situação de plurilinguismo concorrencial que acabamos de descrever, a atribuição de um nome a uma criança, ou a busca de um nome por um adulto, implica a utilização de uma das línguas referidas. ${ }^{24}$ Essa escolha remete-nos para além da função que o nome desempenha na designação social do indivíduo e no processo de individualização comunicacional - quer se trate do nome próprio, quer estejamos a considerar o nome de família ou mesmo o sistema de constituição dos nomes pessoais a partir da sua inserção familiar. O processo de atribuição dos nomes é um sinal de uma forte opção de pertença, de identificação com o grupo de falantes da língua eleita, ou pelo menos de demarcação/oposição ao grupo de falantes da língua preterida. Esta concepção está na base do exercício de análise empírica que se segue. O carácter pouco sistematizado do exercício remete para a forma como, à medida que a minha presença em Timor-Leste foi avançando, ao longo de um período de cerca de ano e meio, me fui apercebendo de diversas possibilidades de explorar empiricamente as hipóteses que esse convívio quotidiano com timorenses ia gerando. O carácter exploratório dessas várias vias de acesso a informação sistemática está, pois, patente na secção que se segue. Entendam-se as suas peças como as pedrinhas de um mosaico ou as manchas de tinta numa pintura impressionista.

\section{LÍNGUA, NOME E IDENTIDADE: ESTUDO DE CASOS}

\section{A liderança da guerrilha}

Taur Matan Ruak, actualmente brigadeiro-general responsável pelas forças armadas timorenses, foi o quarto e último comandante da guerrilha que actuou no território até 1999. Sucedeu no posto a Nicolau Lobato (morto em 1978), Xanana Gusmão (capturado pelas forças indonésias em 1992) e

24 Em termos estritos, a questão é um pouco mais complicada, uma vez que é corrente encontrarem-se indivíduos que possuem dois nomes: um nome em língua autóctone atribuído à nascença, e outro em "língua de cultura" adoptado no baptismo ou no registo oficial. O primeiro pode subsistir no seio da família mais próxima, mas o segundo é claramente o nome de socialização do indivíduo. É sobre este último que incidiremos. Veja-se que, por exemplo, as crianças que morrem antes de ter podido ser baptizadas, são identificadas nas suas campas como “anjos” - e nenhum nome cristão lhes é dado. 
Konis Santana ${ }^{25}$ (falecido prematuramente em 1998). Num recente artigo, Taur explica a relação entre a organização da resistência à invasão indonésia e a língua portuguesa, sustentando que três factores terão pesado na decisão da liderança do movimento de resistência de manter o uso da língua portuguesa: (a) a presença de intelectuais falantes dessa língua, cujo contributo para a formação da estrutura militar da guerrilha terá sido considerável; (b) a existência entre os timorenses conhecedores da língua escrita de um elevado número de indivíduos que se exprimiam em português; e ainda (c) o facto de ser uma língua ortograficamente estabilizada e desenvolvida (Ruak 2001). A chamada "Frente Armada" manteve o uso do português, acrescentando Taur que essa seria "uma arma para contrapor à língua malaia no âmbito da luta cultural". Poderemos sugerir que o uso da língua portuguesa acrescentava dificuldades de entendimento dos documentos que pudessem cair em mãos indonésias.

A verdade, porém, é que ao longo dos anos de resistência as dificuldades cresceram "porque aquela classe detentora da língua portuguesa minguou fatalmente, e esta quase desapareceu da circulação, à excepção de certas correspondências entre os poucos dirigentes de topo ainda sobreviventes". Aliás, o Museu e Arquivo da Resistência ${ }^{26}$ testemunhará a persistência da língua portuguesa como língua preferencial de comunicação escrita entre a liderança política durante todo o tempo da luta armada.

Também outros sectores da resistência utilizaram a língua portuguesa. Recordemos que, tanto por ocasião da visita de João Paulo II, quer depois do massacre de Santa Cruz, os meios de comunicação internacionais imprimiram ou emitiram várias imagens de manifestações em Timor-Leste nas quais a língua portuguesa era sistematicamente utilizada: Pátria ou Morte! Resistir é Vencer! etc.

Em claro contraste com esta defesa política e pragmática do uso da língua portuguesa, vejamos o que ocorreu no seio da guerrilha relativamente ao nome pelo qual os guerrilheiros se quiseram tornar conhecidos. Com a colaboração de alunos da UNTL e ainda com a ajuda preciosa de Álvaro de Castro (elemento activo na frente armada entre 1975 e 1981, profundo conhecedor das peripécias dessa luta), foi possível elaborar o quadro seguinte em que se sistematizam dados referentes aos nomes "cristãos", aos nomes "gentios" e aos "nomes de guerra" de um punhado significativo de comandantes da guerrilha timorense (quadro 1). A publicação recente de um guia do Museu e Arquivo da Resistência, com referência a fundos documentais e aos seus instituidores, permitiu prolongar um pouco a recolha de dados (quadro 2). É sobre eles que nos vamos debruçar de seguida.

25 Sobre este, cf. Mattoso (2005).

26 Em organização à época de elaboração deste ensaio e da minha estadia mais prolongada no território. Cabe aqui uma palavra de agradecimento ao professor José Mattoso, que cuidou da organização deste precioso arquivo, a quem se deve a gentileza desta comunicação. 
Quadro 1

Nomes cristãos, gentios e de guerra de alguns guerrilheiros e seus líderes

$\begin{array}{lll}\begin{array}{l}\text { Nome "cristão" } \\ \text { José Alexandre Gusmão } \\ \text { José Maria Vasconcelos }\end{array} & \text { Nome "gentio" } & \begin{array}{l}\text { Nome "de guerra" } \\ \text { Kay Rala } \\ \text { Francisco Guterres }\end{array} \\ \begin{array}{l}\text { Taur Matan Ruak } \\ \text { Antonio Carvarino }\end{array} & \begin{array}{l}\text { Mau Lear } \\ \text { Hélio Pina }\end{array} & \\ \text { Manuel Soares } & \text { Mau Kruma } & \\ \text { Lucas da Costa } & \text { Asu Coli } & \\ \text { Tito dos Santos } & \text { Coli Mau } & \text { Lere Anan Timor } \\ \text { Jaime dos Santos } & & \text { Samba Sembidan } \\ \text { Inácio dos Santos } & & \text { Naroman } \\ \text { Filomeno Paixão } & & \text { Susar Blehitu } \\ \text { António de Carvalho } & & \text { Fera Lafaek } \\ \text { Domingos da Costa } & & \text { Ular } \\ \text { Domingos da Costa } & & \text { Falur Latelaek } \\ \text { Alberto Nunes } & \text { Plin Plan } \\ \text { Álvaro da Costa } & \text { Letribus Na'i Buti }\end{array}$

Fonte: Álvaro da Costa e estudantes da UNTL

Como é claramente visível, o traço saliente é o desaparecimento completo da língua portuguesa e a adopção de "nomes de guerra" ou o retorno aos nomes "gentios" formados por vocábulos originários das diversas línguas autóctones - mambai, makasai, fataluku, etc. Poderemos compreender que assim tivesse sido quando recordamos que as estimativas do número de falantes de língua portuguesa aponta para números muito baixos e para a sua grande concentração em Díli (e em menor medida nos postos administrativos espalhados pelo território), e quando um desígnio estratégico da liderança política consistia no estabelecimento de laços fortes entre todas comunidades - com particular relevo nas comunidades excluídas do uso da língua portuguesa - e os elementos da guerrilha. Devemos incluir entre estes laços aqueles que se prendem com a afectividade: o uso de nomes familiares às comunidade seria um elemento com peso nessa estratégia.

A força deste argumento poderia ser maior se a língua escolhida tivesse sido sistematicamente o tétum-praça, o que não é manifestamente o caso. Isto porque, conforme sustenta Leão da Costa, também a difusão da língua tétum (nomeadamente pela Igreja Católica) pode ser entendida como uma forma de 
Quadro 2

Quadro de nomes de elementos da Resistência Timorense cujos fundos documentais se encontram no Museu e Arquivo da Resistência

$\begin{array}{ll}\text { Nome “cristão" } & \text { "Nome de guerra" } \\ \text { Leandro Lobato } & \text { Grei Harana } \\ \text { Alberto da Costa Freitas } & 14-12 \\ \text { João dos Santos } & \text { Sina Makassar } \\ \text { Jacinto Viegas } & \text { Roke } \\ \text { Jaime Romão dos Santos } & \text { Dotim } \\ \text { Ernestina Maia Gouveia Leite } & \text { Angrek } \\ \text { Anastácio de Jesus } & \text { Russa Fuik } \\ \text { Danielda Cruz } & \text { Kameli } \\ \text { Cirilo de Jesus Amaral } & \text { N'a Amau } \\ \text { Gaspar Gonçalves } & \text { Piti Lisidi } \\ \text { Álvaro do Nascimento } & \text { Sesurai } \\ \text { Francisco Doutel Sarmento } & \text { La Mesaik } \\ \text { Simão Augusto } & \text { Sito } \\ \text { Eduardo Belo Soares } & \text { Gattot } \\ \text { João Lay da Silva } & \text { Besi Mean } \\ \text { António Soares } & \text { Tata Mailau } \\ & \text { Piti Lakon Mosu } \\ & \text { Cohen } \\ & \\ & \text { Sabalae } \\ & \end{array}$

Fonte: Resistência Timorense - Arquivo \& Museu.

resistência activa à imposição do bahasa indonésio por parte do invasor (Costa 2003: 16). Pelo contrário, encontramos no rol dos nomes de guerra vocábulos oriundos de várias línguas com expressão geográfica concentrada e muito localizada, como as línguas galoli ou fataluku. Porém, os meus informadores são peremptórios em afirmar que, apesar do mosaico linguístico que emana do quadro apresentado, a vinculação dos guerrilheiros às comunidades locais passava pelo reconhecimento dos seus nomes como nomes genuinamente "timorenses". Tal aspecto poderia ser reforçado se os nomes de guerra assumissem um carácter descritivo ou evocativo de uma realidade natural ou fantástica, que parecem coadunar-se com formas de pensamento mágico. Alguns nomes comportam essa dimensão (Taur Matan Ruak= gibóia de dois olhos; Falur Latalaek= pomba sem sepultura), mas estamos longe de ter encontrado uma regularidade suficientemente forte para a admitirmos como factor explicativo global. 
A sugestão que parece poder colher maior aceitação consiste em reportar a escolha destes nomes à tradição bélica da ilha. Segundo se diz - o que constitui uma razão suficientemente forte - seria costume em tempos idos que os chefes políticos locais, os liurai, adoptassem "nomes de guerra" simplesmente distintos dos que normalmente utilizavam. Ou seja, estaríamos perante uma espécie de pseudónimo guerreiro. A escolha reporta-se, pois, a um contexto em que se deseja vincar uma ligação simbólica com a tradição mais profunda da ilha - ligação que alguns dos comandantes da guerrilha efectivamente possuíam em termos de origem familiar, mas que, mais uma vez, não pode ser generalizada.

Como um poeta timorense exprimiu:

\section{O braço armado do Povo}

As Falintil,

Intimamente preocupadas,

A Deus pedem protecção

$E$ dos defuntos a companhia. ${ }^{27}$

Aqui se revela o sincretismo de um corpo de guerrilha que recebe contributos das mais variadas origens: desde a elite urbana (versada na literatura de guerrilha maoísta ou de Vo Nguyen Giap tão presente nas bancas portuguesas em $1974 / 75)^{28}$ à religião institucional e às formas de culto ancestrais.

A língua portuguesa era o meio de expressão da condição de elite política no contexto de Timor-Leste em 1975. Nesses termos, a língua portuguesa unia dois sectores fundamentais dessa elite: ${ }^{29}$ filhos de chefes locais tradicionais (de que se pode citar o exemplo de Francisco Xavier do Amaral, fundador da FRETILIN e filho de um liurai de Turiscai, Same) e os filhos da classe média urbana que se estava a constituir em Díli após a II Guerra Mundial, alguns dos quais com origem portuguesa. ${ }^{30}$ Para que essa elite pudesse manter o seu estatuto no contexto da invasão e da opção pela luta armada (em que apenas uma fracção dela se integrou), a prioridade não consistia em afirmar os traços marcantes da sua diferença, mas antes em sublinhar, com todos os meios ao seu alcance, a sua imersão na água primordial da cultura dos antepassados comuns - a cultura que poderia justificar a oposição à invasão “javanesa”, como então se dizia. Não era a proximidade do falar português que merecia destaque, mas sim a capacidade de interpretar as tradições bélicas que se exprimiam em línguas autóctones.

27 Álvaro de Castro, excerto do poema inédito "Reminiscência", por gentileza do autor. Trata-se de um poema escrito em ttétum e traduzido pelo próprio autor.

28 Terá sido pela via dos estudantes do território sediados em Lisboa que terá chegado a Timor.

29 Agradeço a Ágio Pereira, elemento importante na vida política timorense desde o 25 de Abril de 1974, pelos esclarecimentos prestados e pela formulação da hipótese esboçada.

30 Para uma avaliação da evolução de Díli antes de 1974, veja-se Thomaz (1994: 682-689). 
Curiosamente, é um elemento marginal em relação a essa elite de 1975 quem emerge nos anos de 1980 como líder incontestado da resistência e protagoniza esse fundamental projecto de recomposição política e social até ao sucesso do CNRT (Conselho Nacional da Resistência Timorense): José Alexandre/Kay Rala/Xanana Gusmão.

\section{Os formandos do Centro Nacional de Emprego \\ e Formação Profissional (CNEFP) ${ }^{31}$}

Em Tibar, nos arredores de Díli, funciona há anos um centro de formação profissional. Neste centro, timorenses provenientes dos quatro cantos do território, seguem cursos de formação profissional como electricista, canalizador, pedreiro e carpinteiro. São, geralmente, jovens adultos com formação académica básica que não podem ser considerados como membros das elites do país. Olhar para os indivíduos que passaram nos últimos anos por esta instituição poderá permitir uma aproximação a um retrato das práticas culturais - e especialmente práticas de nomeação - com raízes espalhadas pelo território

A base de sondagem de que parto para esta secção é constituída por uma listagem de alunos que frequentaram os cursos do CNEFP entre 2002 e 2005. No total, comporta 305 nomes completos de alunos provenientes de todo o país. Desses 305, 178 permitem saber o ano de nascimento do estudante - o que, como procurarei evidenciar, se torna relevante para os propósitos deste exercício. Assim, procedeu-se a uma selecção daqueles sobre os quais havia a certeza de terem nascido depois de 1979 (considerando essa a data da afirmação do domínio efectivo do invasor indonésio sobre todo o território). Obtivemos um conjunto de 105 indivíduos, aos quais retirámos as mulheres por serem apenas 9 e, portanto, sem suficiente representatividade. Os restantes 96 constituem o núcleo sobre o qual assentam as observações que se seguem.

Recordemos que, em Timor-Leste, é costume atribuir a uma criança um nome logo após o seu nascimento. Geralmente, este nome é um nome gentio, ou seja, um nome que usa as línguas autóctones do território. É igualmente frequente que este nome perdure: muitos dos meus informantes revelaram, quando interrogados, os seus nomes gentios e admitiram que o uso desses nomes se mantém no seio da família próxima - com regularidade nos primeiros anos de vida, com crescente irregularidade à medida que as crianças se transformam em adolescentes e em jovens adultos. Quer dizer: à medida que o seu círculo de sociabilidade se alarga, o nome "familiar" perde peso como elemento de identificação.

Em tempos idos, a conversão religiosa - nomeadamente a adesão à religião católica com o consequente baptismo - oferecia uma oportunidade para

31 Esta secção foi tornada possível pela colaboração do director do CNEFP, Pedro Fraga, a quem muito agradeço a gentileza. 
"mudar de nome": era esse o momento de adoptar um nome cristão. Ao contrário de alguns territórios do Pacífico, onde a presença colonial não provocou uma opção generalizada por nomes novos, Timor-Leste parece ter seguido uma via de desvalorização dos nomes gentios no processo de formalização administrativa, pelo menos até a um passado muito recente.

Durante o período de ocupação indonésia, assistiu-se a um reforço significativo das práticas administrativas modernas. Os indivíduos passaram a necessitar de um instrumento de identificação para poderem frequentar as escolas, os centros de saúde, as repartições públicas. A questão do nome (da sua definição e da sua fixação) assumiu, então, mais que uma função de identificação comunitária, uma função de interacção com uma sociedade mais vasta.

A nível constitucional, a República da Indonésia permite que os seus cidadãos optem entre várias denominações religiosas - incorporando, portanto, elementos de um estado laico e de liberdade de culto. Este quadro normativo vigorou em Timor-Leste as partir dos finais dos anos 70. Na década seguinte, parece ter sido reforçado por um recenseamento geral da população, que era "convidada" a indicar a sua filiação religiosa. Seja como for, o que parece razoável afirmar é que, na década de 1980, se assistiu a uma pressão no sentido de registar oficialmente o nome pelo qual os indivíduos optavam por se fazer conhecer no meio social abrangente. Por esta razão, observar o nome daqueles que nasceram nessa década pode permitir entrever a teia social em que as práticas de nomeação se inserem.

Antes, porém, deveremos procurar esclarecer o que entendemos por "nomes portugueses" ou, de uma forma mais específica, nomes "em língua portuguesa". Desde logo, devemos descartar uma perspectiva estritamente ortodoxa que nos remetesse para as práticas de nomeação vigentes em Portugal, por grosseiro pecado etnocêntrico. Ainda mais, devemos fugir da listagem normativa que as autoridades portuguesas utilizam nos tempos que correm para ajuizar da "portugalidade" de um qualquer nome que os pais queiram atribuir aos seus filhos. ${ }^{32}$ Interessa-nos, obviamente, circunscrever a nossa discussão à língua portuguesa tal como ela se fala em Timor-Leste.

Uma hipótese de trabalho, que foi desenvolvida por Maria José Albarran de Carvalho, consiste em estudar nomes de origem histórica portuguesa e analisar a evolução a que estiveram sujeitos numa perspectiva etno-linguística (Carvalho s/d). Os resultados deste estudo, se bem que importantes para a história da presença dos portugueses na zona e das redes comunicativas por eles estabelecidas, apresenta uma limitação para a perspectiva que aqui desejo defender que merece ser discutida. Na base desse projecto está a identificação de uma matriz portuguesa documentada (caligraficamente, epigraficamente) e a aplicação de

32 Essa listagem e a sua fundamentação (que pode ser resumidamente encontrada no site www.dgrn. mj.pt) mereceria bem uma investigação de fôlego. 
uma ferramenta linguística que dê conta do trajecto até à forma actual - por vezes já distante do original. Ora, a questão que se coloca é que, ao ouvido de um timorense, pode pertencer à "língua portuguesa" um vocábulo ou uma expressão que não se enquadre nem no português canónico, nem na derivação linguística a partir de uma origem portuguesa. Quero com isto dizer que o conceito de "língua portuguesa" presente na sociedade timorense dos nossos dias - e presumivelmente no passado recente - é uma construção cultural que, sendo genericamente edificada sobre uma base objectiva de articulação com a língua portuguesa canónica, pode conter alguns elementos de desvio, de reinterpretação, ou mesmo de inovação. Conforme a própria autora reconhece, "trata-se de uma variável do Português que se demarca do Português Europeu Contemporâneo, numa identidade lexical, fonológica, etc., muito própria" (2001: 72).

Mas esta constatação talvez não baste: perante uma expressão que eu próprio não compreendo, e que me é apresentada como sendo "uma expressão em língua portuguesa", não posso deixar de considerar que o dilema deve ser ultrapassado pela consideração positiva de ambas as afirmações. É que, no âmbito da presente discussão das práticas de nomeação, o conceito de "língua portuguesa" não é linguístico - é cultural. Neste sentido, portanto, a afirmação da autora segundo a qual a língua portuguesa "é a língua dos nomes próprios e sobrenomes de, respectivamente, 98\% e 70\% dos timorenses" (2001: 71 ) deve ser tomada cum grano salis - apesar de, em termos gerais, indicar e dar expressão a um fenómeno fundamental no complexo identitário timorense.

Voltemo-nos, então, para os dados empíricos recolhidos em Timor-Leste, começando pelos "nomes próprios". Da listagem de 96 formandos do CNEFP, apenas um ostenta um nome próprio que imediatamente excluiríamos da categoria local de "nome português": Mardojony Henry - apesar de o seu sobrenome ser Madeira. Outro caso oferece dúvidas: Firman Nelson Amaral - sendo que "Firman" não é um nome "indonésio" nem "gentio". O caso de Joni Martins também apresenta uma ambiguidade: se pode ser visto como um diminutivo do inglês John/Johnny, ele grafa-se "à portuguesa”.

Contudo, olhando para os restantes, somos confrontados com aspectos não-correntes no português canónico, como:

a) a utilização de sobrenomes como nomes próprios (evidente no caso de Nunes, mas também possível de verificar em nomes como Baptista que, em Portugal, correm sobretudo como sobrenome);

b) nomes que evidenciam um contacto débil com o português escrito e uma prevalência da língua falada, como no caso de Zaquiel Carvalho (por Ezequiel);

c) a consagração como nomes próprios de formas usadas no continente europeu na linguagem coloquial ou como hipocorísticos, tais como Carlito (de Carlos), Manecas e Nelito (de Manuel), a que talvez se possa 
acrescentar um Juninho - nome derivado de uma raiz desconhecida por sufixação tipicamente portuguesa.

Todas estes casos ilustram o português de Timor-Leste como um "português desviante" da norma europeia. Trata-se de formas possíveis de adaptar às realidades locais um instrumento linguisticamente identificável.

A primeira tentação é de afirmar que os nomes próprios não identificados na escolha acima são "portugueses", sem para tal ser preciso fazer quaisquer ressalvas sobre o significado atribuído a “portugueses”. Não está a lista repleta de nomes próprios como Ângelo, António, Armando, Augusto e tantos outros que conhecemos do dia-a-dia lusófono, tais como Bernardino, Cristóvão, Domingos, Estanislau, Feliciano, Guilhermino, Henrique, Inácio, Júlio, Laurentino, Marcelino, Nelson, Olívio, Pascoal, Raimundo, Simplício, Tomás, Vicente, Xavier ou Zacarias? ${ }^{33}$ A variedade de nomes próprios é tão extensa que, nestes 96 indivíduos, detectamos como primeiros nomes (em nomes simples ou complexos) 74 ocorrências distintas, mais 12 ocorrências como segundos nomes: um total de 86 nomes individuais distintos para 96 casos! Os nomes que mais vezes aparecem repetidos - António, João e José - ocorrem apenas quatro vezes como primeiro nome. Pode-se dizer que encontramos quase tantos nomes (isolados) como indivíduos, o que demonstra uma enorme capacidade para manipular adequadamente uma pool de nomes com o fim de proporcionar uma identificação inequívoca.

A surpresa estava para chegar: no confronto da lista de nomes recolhidos com a dos "vocábulos admitidos e não admitidos como nomes próprios" no banco de dados da Direcção Nacional de Registos e Notariado da República Portuguesa. ${ }^{34}$ Esperava encontrar resistência à consagração de diminutivos, por exemplo. Mas o espectro de rejeição foi muito maior. Não são admitidos como nomes próprios em Portugal os vocábulos Nero ou Agapito - mas a razão desta decisão não é certamente linguística, uma vez que é reconhecido que ambos são vocábulos perfeitamente identificados com a língua portuguesa e mesmo como nomes próprios (os nomes dos imperadores romanos passaram quase na totalidade à língua portuguesa, e Agapito é nome histórico!). Não podem as crianças portuguesas ser baptizadas como Milton - mas ninguém ignora que no Brasil este é um nome muito comum.

A verdade, porém, é que em Timor-Leste foi (e é) possível atribuir a um menino o nome de Adeomar (próximo do português canónico Ademar) ou Benvindo (masculino de Benvinda, nome de mulher em português, que não aceita o masculino), Averio, Azitio ou Atanásio, Crisanto ou Elígio, Evério,

33 Para construir esta listagem de A a Z (sem Q nem U) foi necessário recorrer ao lote completo de 305 nomes, e incluir alguns (Xavier) que aparecem como sobrenome.

34 www.dgrn.mj.pt. 
Florindo ou Juvêncio ou Juviano, Railando, Trifónio e até Estrósio. Todos eles se encontram fora da lista dos "vocábulos admitidos como nome próprio" em Portugal. Todos eles evocam uma sonoridade portuguesa. Todos eles são entendidos pelos timorenses como "nomes portugueses".

Se adoptarmos como critério de identificação de "nomes portugueses" o conceito dos timorenses que os usam e não o das autoridades civis portuguesas, ou ainda a matriz puramente histórico-linguística (qual a origem de Estrósio?), então temos de concluir que os "nomes portugueses" constituem a esmagadora maioria dos nomes próprios usados no território - e dos nomes próprios dados a crianças no auge da dominação indonésia.

Vejamos agora o que se passa no domínio dos sobrenomes (ou nomes de família). Na nossa amostra de 96 indivíduos, metade (uma proporção altíssima se comparado com Portugal ou o Brasil) tem apenas um sobrenome; outra metade forma o seu sobrenome a partir de mais que um nome. A lista de nomes revela 59 sobrenomes diferentes. Combinando as duas situações, o nome que mais vezes surge é Ximenes (com 8 ocorrências), seguido de Martins e Silva (7 ocorrências), Soares (6) e Assis, Costa, Freitas e Santos (5 cada). Nomes que identificamos como não-portugueses, todos de ocorrência singela, são apenas 6: Bere, Galosu, Lim, Obe, Poto e Yilman.

A sugestão que parece decorrer destes dados é que não há uma preocupação conservadora na atribuição de nomes, já que vigora uma extensa pool de nomes - tanto de nomes próprios como de sobrenomes (sendo que alguns, como Afonso ou Xavier, são usados das duas formas) onde a língua portuguesa corresponde a mais de $90 \%$ de ambos os casos. O entendimento que aqui se dá da "língua portuguesa" abarca o que poderíamos considerar "neologismos" como Estrósio (nome próprio) ou Eco (sobrenome).

Ao olharmos para o panorama dos nomes tal como nos aparece aqui revelado verificamos que, na década de 1980, um indivíduo ou uma família timorense que tomava um nome "português" podia escolher quase livremente o nome próprio e o sobrenome. Este exercício sugere que, nessa época, os nomes "portugueses" se tinham tornado absolutamente dominantes entre a população timorense, apesar da proibição oficial do uso da língua, mas beneficiando da cobertura que as autoridades religiosas davam a esta forma de revelação de uma cultura de oposição à assimilação na grande nação indonésia - o que se verificaria tanto entre as autoridades católicas, de longe as mais representativas, como de outras denominações, tal como me foi possível verificar num breve exercício realizado em Beloi, Ataúro, junto de uma comunidade dominantemente protestante.

\section{Uma sondagem em registos paroquiais (Dare)}

A paróquia de Dare situa-se na montanha sobranceira a Díli, distando a sua igreja pouco mais de dez quilómetros da cidade. Foi nesta paróquia que, graças à anuência do Padre Lúcio Norberto de Deus, pude aceder ao rico espólio 
documental pertencente à Igreja Católica local. A sondagem que pude realizar nesse espólio dirigiu-se em dois sentidos: por um lado, utilizando os índices dos livros de registo de baptismo, procedi ao levantamento completo dos nomes próprios atribuídos aos indivíduos baptizados no decurso do ano de 1995 - um ano que poderá ser visto como representativo da situação geral vivida nas vésperas do desencadeamento do processo que haveria de conduzir à restauração da independência nacional; por outro lado, utilizando os próprios registos de baptismo, procurei recolher para cada indivíduo baptizado o maior volume de informação possível. A presente secção baseia-se, pois, nos dados obtidos desta forma na paróquia de Dare.

O levantamento dos antropónimos usados como nome próprio incidiu sobre um universo de 886 indivíduos, que partilhavam um total de 431 nomes singulares. Tal representa em média a partilha de um mesmo nome por dois indivíduos; média baixa, indicadora da facilidade de identificação positiva a partir deste elemento, que é corroborada pelo facto de 264 desses nomes - ou seja, 61,25\% dos casos - surgirem apenas uma vez. Desde logo, observamos uma predominância absoluta de nomes "em língua portuguesa" (cf. Anexo I).

Se procurarmos testar a frequência com que os nomes mais utilizados se manifestam, verificaremos o seguinte: apenas sete casos surgem dez ou mais vezes - Maria (28), José (16), Domingos (13), António (12), João (1 1), Isabel (10) e Domingas (10). Todos estes nomes são, indubitavelmente, nomes "em língua portuguesa”, língua proibida no território na data em que os baptismos ocorreram.

O segundo exercício consistiu no levantamento de todos os dados familiares contidos nos registos de baptismo desta paróquia. Dado o volume de registos houve que proceder a uma sondagem arbitrária. Escolheram-se, pois, os registos referentes ao mês de Agosto dos seguintes anos: 1970 (administração portuguesa) - 17 registos; 1980 (pouco tempo decorrido sobre a invasão indonésia) - 62 registos; 1990 (situação de integração consolidada) - 84 registos; 2003 (após a independência) - 14 registos.

Os dados referentes a 1970 revelam que os indivíduos baptizados eram jovens, podendo ser divididos em três categorias: bebés com menos de 1 ano ( 8 casos $=47 \%)$; crianças com idades entre 1 e 10 anos (apenas 2 casos $=12 \%$ ); e adolescentes com idades entre os 10 e os 14 anos $(7$ casos=41\%). Não ocorrem baptismos de adultos. Partindo desta amostra, chegamos a 14 casais (uma vez que há três casos de irmãos, um dos quais de gémeos) de pais, e 28 casais de avós. Ora, se a totalidade dos nomes das crianças baptizadas revela a utilização da língua portuguesa, o mesmo não se passa com as gerações anteriores. No caso da geração de pais, 19 dos 28 indivíduos possuem nomes em língua portuguesa e 9 em línguas autóctones - sendo que todos estes são pais de adolescentes. Na geração dos avós, apenas 12 dos 56 indivíduos têm nomes portugueses, enquanto 44 têm nomes gentílicos. 
A formação do nome completo dos indivíduos baptizados (isto é, nome próprio mais sobrenome) revela duas situações praticamente equilibradas: nove crianças recebem, na tradição portuguesa, sobrenomes pertencentes ao nome dos seus pais; seis recebem os sobrenomes dos padrinhos; e duas crianças recebem nomes que não identificam nem os pais nem os padrinhos. Um exemplo é o de João Rego da Silva, no gentilismo Mau Perça, nascido a 5 de Março de 1958, filho de Lelo Bere e de Soi Mau, neto paterno de Mau Mali e de Bui Rai, e materno de Lelo Bere e de Oleça, e que teve por madrinha Matilde Pereira de Jesus e por padrinho a devoção a um santo.

A adopção de um modelo tão aberto dificulta a compreensão das relações de consanguinidade. Veja-se como o casal constituído por Miguel Mesquita do Rego (filho de Paulino de Deus Maia e de Paulina Barreto Maia) e sua mulher Teresa (filha de Peti Mau e de Bi Hode) baptizaram a 14 de Agosto de 1970 dois filhos: Marcos de Jesus (afilhado de Pedro de Jesus) e Emília do Rego (afilhada de Alberto Lemos do Rego e de Maria Isabel do Rego).

Saltando para 2003, novo panorama nos aparece. Tal como no tempo da administração portuguesa, o baptismo é um acontecimento reservado a crianças - neste caso 10 delas têm menos de um ano e quatro entre um e cinco anos. Agora, porém, todos os pais foram registados como portadores de nomes em língua portuguesa e os nomes completos das crianças formam-se a partir dos nomes dos progenitores - embora em modalidades diferentes. E nos 26 casais de avós identificados (mais uma vez ocorre um caso de baptismo de irmãos), 35 indivíduos possuem nomes "portugueses" enquanto 17 mantêm nomes tradicionais timorenses.

Em relação a estes dois anos extremos, tanto em 1980 como em 1990, a situação observada é substancialmente distinta. Desde logo, os baptismos não eram reservados a crianças e jovens. Encontram-se baptismos de indivíduos entre as poucas semanas de idade e os 64 anos - simbolizando de modo expressivo a emergência de um papel social novo por parte das autoridades eclesiásticas católicas e uma nova relação entre elas e o conjunto da população timorense. Em 1980, 20 dos 62 indivíduos baptizados (32\%) tinham idades superiores a 20 anos, enquanto 18 (29\%) teriam menos de um ano. Nos registos de 1990 os números são, respectivamente, de 18 (21\%) e de 17 (20\%) num total de 84 . Estes números evidenciam que, nessa época, se assistia a uma profunda mudança em curso na sociedade timorense, que aqui tem um dos seus afloramentos.

A formação dos nomes completos segue também um modelo muito mais definido nestes anos: o da adopção de sobrenomes derivados dos padrinhos - o que sucede em 43 casos sobre 62 possíveis (69\%) em 1980, e em 70 em 84 (83\%) em 1990. A adopção de nomes derivados dos pais apenas ocorre oito vezes (13\%) em 1980 e quatro (5\%) em 1990, havendo modelos mistos e mesmo recurso a outros nomes sem qualquer vínculo conhecido. Dado o 
movimento de baptismos tocar o conjunto da sociedade e não apenas o seu estrato etário mais jovem, a proporção de indivíduos cujos pais e avós possuíam nomes tradicionais é extremamente elevada.

Surpreendem-se, nestes registos, fenómenos curiosos, cuja discussão nos poderia levar muito longe: por um lado, baptismos de famílias inteiras; por outro, a intervenção de indivíduos em diversas situações - pais num caso, padrinhos noutro, ou ainda baptismos que precedem outros actos. Por exemplo, no dia 8 de Agosto de 1990 foi baptizado Domingos Sarmento Pereira, nascido a 25 de Janeiro de 1935, filho de Manuel e de Sineta, neto paterno de Vinte e de Saraman e materno de Mau Duau e de Colelo; foram padrinhos António Sarmento Pereira (que lhe deu o sobrenome) e Elisa Nascimento.

No mesmo dia baptizou-se Domingas Carvalho Santos, nascida a 13 de Maio de 1940, filha de Mau Liqui e de Silequi, neta paterna de Lacanó e de Bilequi e materna de Lequi Mau e de Lequi Mali; foram padrinhos Paulo de Carvalho e Maria Pereira dos Santos (que forneceram elementos para o sobrenome). No dia seguinte, Domingos e Domingas haveriam de contrair matrimónio na mesma paróquia. Entretanto, fizeram baptizar três filhos que tinham: Augusto Sarmento Soares (afilhado de José Rebelo e de Domingas Sarmento Soares); Ana Costa Sarmento (afilhada de Carlos e de Guilhermina Costa Sarmento); e Lúcia Ribeiro da Silva (afilhada de João Ribeiro Soares e de Alda da Silva).

Em 5 de Agosto de 1980, Manuel Marques Rego e sua mulher Balbina Sarmento Lobo baptizaram o filho nascido em 7 de Março, que ficou registado como Constâncio Marques. Logo de seguida, Balbina serviu de madrinha a uma menina de seis anos, filha de Mau Huno e de Sara Bau, que se chamou Cristiana de Jesus Sarmento Lobo, e a outro menino, filho de Mau Cana e de Sara Mau, a que puseram o nome de Clementino Marques Lobo.

Regressando ao nosso problema central, o que este conjunto de fontes nos revela é a súbita transformação ocorrida na sociedade timorense após a invasão indonésia, que levou ao baptismo sectores amplos da população de qualquer escalão etário. Este fenómeno foi observado por Durand (2004: 159), que afirma que a população baptizada terá passado de cerca de um quarto a mais de três quartos num espaço de tempo relativamente curto. Ora esta transformação foi acompanhada, por via de regra, pela adopção de nomes "em língua portuguesa", tanto a nível do nome próprio como dos sobrenomes. As regras de atribuição destes últimos parece começarem por admitir, em alternativa, nomes dos pais e nomes dos padrinhos (caso de 1970), para depois se fixarem claramente na adopção de nomes dados pelos padrinhos (1980, 1990). Mais recentemente, passaram a seguir o modelo português de transmissão dos sobrenomes dos pais. Mas, no cômputo geral, e dada a velocidade a que as mudanças operavam, o que é necessário sublinhar é a volatilidade e a plasticidade das regras e a sua articulação com o momento histórico e os desígnios especiais que este motivava. 


\section{CONCLUINDO: UMA NOVA DIMENSÃO DO COMPLEXO IDENTITÁRIO}

Retiremos desta discussão, por um lado, que os nomes "portugueses" adoptados em Timor-Leste, sobretudo durante o período de ocupação indonésia, integram uma extensa lista, muito aberta a situações de inovação e de invenção e, por outro lado, foram em grande parte escolhidos em bloco; quer dizer, incluindo conjuntamente o que, em Portugal, seria um nome próprio e um sobrenome. Este último fica, assim, separado da função de constituição de espessura geracional que lhe é atribuída na maior parte dos contextos lusófonos. As circunstâncias históricas em que se deu a adopção generalizada deste tipo de nomes distinguem a situação de Timor de qualquer outra no mundo lusófono e implicam que o quadro comparativista que preside a este colóquio seja alargado para incluir esta situação.

O convite que me foi dirigido para participar neste simpósio sugeria que me dedicasse a uma articulação entre, por um lado, "nomes e pessoas", e por outro, "género, classe e etnicidade". Cabe-me reconhecer que os três elementos referidos em segundo lugar estão praticamente ausentes das minhas palavras - outra investigação terá de ser futuramente realizada nessa direcção, já que o exemplo timorense sem dúvida será rico nessa matéria. ${ }^{35} \mathrm{O}$ aspecto da proposta inicial que guiou a minha exploração deste material foi a questão da complexidade identitária. No caso de Timor-Leste, a componente política, no sentido de actividade da polis (i.e., as interacções públicas e as relações de poder dos vários estratos sociais que constituem uma nação) assumiu num passado recente e de que ainda nos chegam ecos, um peso significativo na estruturação dessa identidade, e projectou-se sobre o processo de nomeação dos indivíduos.

A sociedade timorense enfrentou problemas de magnitude incalculável: uma invasão militar que, nos primeiros quatro anos, terá sido responsável pelo desaparecimento de cerca de duzentos mil cidadãos (numa população de cerca de setecentos mil); uma invasão administrativa que, ao mesmo tempo que estendia os ramos de oliveira de estradas, escolas e hospitais (com que nos entretemos a medir e a cartografar as rotas de um progresso por vezes juncado de cadáveres), trazia consigo uma religião - muçulmana - que apenas conseguia uma fraquíssima adesão no território; uma língua nova - o bahasa indonésio - imposta como língua de cultura; um governo que pretendia, pelas forças combinadas do extermínio, da conversão e da imposição de quadros de referência comuns às restantes partes da constelação indonésia, promover a assimilação e apagar as marcas distintivas deste povo.

Enfrentaram os timorenses este problema com uma estratégia de resistência - aproveitando todas as pequenas liberdades para recusar a assimilação que

35 A título de mera indicação, veja-se o Dicionário Tétum-Português, de Luís Costa, onde o autor apresenta um conjunto de nomes timorenses, distinguindo entre nomes masculinos, femininos e comuns aos dois géneros. 
lhes era imposta e para continuar a afirmar a sua autonomia. As formas que usaram para esse objectivo foram, seguramente, muito variadas. Entre elas, as práticas de nomeação - com uma capacidade plástica de responder a situações diversificadas - aparecem em lugar cimeiro. Que maior afronta ao invasor se poderia imaginar do que a recusa obstinada em adoptar os seus nomes, em jogar, ao nível de uma norma de sociabilidade básica mas dotada de elevado poder simbólico, com as ferramentas oferecidas pelo invasor, mas antes criar ou aprofundar uma tradição ostensivamente confrontacional, de repescar (ou até inventar) nomes portugueses? Note-se que o plurilinguismo que se verifica no território é de tipo concorrencial. $\mathrm{O}$ facto de as autoridades indonésias usarem dos meios mais diversificados para tentar limitar a expressão do português (como, de resto, no resto do país, fizeram com sucesso no caso do holandês) mais realça o alcance da escolha clara por parte dos timorenses do leste de nomes na língua portuguesa. A adesão a uma religião cristã, por si só, não é bastante para explicar.

Num caso, foram elementos de uma elite, socializada na língua portuguesa e com nomes de baptismo portugueses anteriores a 1975, quem se viu na contingência de adoptar nomes de guerra gentios para, desse modo, selar uma relação mais profunda com as comunidades para as quais essa prática representava um reatar de laços de identificação com correntes historicamente enraizadas e uma espessura cultural que se queria, politicamente, manter viva como razão última da resistência. A adopção por parte de muitos elementos da guerrilha e da resistência de nomes de guerra em línguas autóctones, para além da componente conspirativa e de segurança que essa prática evidencia e que é naturalmente comum a situações idênticas, reflecte igualmente o peso que a escolha da língua em que se processa a nomeação tem na configuração da identidade que se deseja construir.

Nos outros casos que passámos em revista, e que dizem respeito ao povo indistinto, o que parece ter-se verificado foi o aproveitamento da oportunidade oferecida pela possibilidade de se registarem como cristãos para escolherem um novo nome em língua portuguesa. Urge tomar em conta duas particularidades deste processo. Em primeiro lugar, os nomes "portugueses" usados pelos timorenses revelam uma dose significativa de invenção e de inovação, não se limitando a reproduzir nomes de origem europeia - desse modo ultrapassando as limitações que o isolamento cultural imposto pelas circunstâncias da integração indonésia poderia acarretar em termos de adequação dos meios aos fins desejados. Em segundo lugar, a distinção entre nome próprio e sobrenome nem sempre pode ser aplicada com rigor; pelo contrário, como vimos no caso de irmãos com sobrenomes diferentes, ou em casos de padrinhos que davam o seu "sobrenome" a afilhados distintos, a formação do nome completo respondia a conjunturas variáveis - sobretudo no período de grande afluxo de timorenses ao baptismo, durante a dominação indonésia. 
De qualquer forma, o uso de nomes "em língua portuguesa" pode ser considerado como esmagadoramente dominante em Timor-Leste a partir da década de 1980, pelo menos até à data da independência, e é um elemento que se situa bem para lá da capacidade dos indivíduos se exprimirem, mesmo que modestamente, em língua portuguesa. A prática quotidiana da vida em Timor ensina-nos rapidamente que não é por um indivíduo se chamar João ou Maria, Afonso ou Susana, que saberá entender uma única frase de português corrente ou exprimir uma ideia básica nessa língua.

Em comum, todos os casos que puderam ser analisados parecem revelar uma sensibilidade muito grande das práticas de nomeação às contingências do processo histórico. $\mathrm{Na}$ verdade, somos levados a reconhecer a presença de um forte elemento de contingência histórica. Sem recuperarmos a contingência dos acontecimentos (o que efectivamente sucedeu num lugar onde outros cenários eram possíveis ou mesmo viáveis), sem recuperarmos esta dimensão de experimentum mundi que é o cerne da história, nunca poderemos compreender, na sua totalidade, a complexidade identitária.

Como nos recorda Carlo Ginzburg, todas as sociedades conhecidas do presente e do passado projectam as suas teias de sentido numa prática comum: a de dar a cada pessoa um nome. Se o fim da ilusão etnocêntrica tornou insustentável a ideia de uma "História Universal", apesar do universalismo das práticas de nomeação, só uma antropologia impregnada de história, ou seja, uma antropologia que entenda as estruturas sociais como um sistema onde o olho de Cronos vigia incessantemente o dia-a-dia dos homens, onde se combinam sincronia e diacronia, poderá fazer jus ao desafio que enfrenta. ${ }^{36}$

Eis o que Timor-Leste tão vividamente nos recorda. E como que querendo afirmar que é uma sociedade viva, começa a dar sinais de mudança. Hoje em dia Timor-Leste vive, com euforia, os primeiros anos da sua independência política. Há sugestões no ar de que se desenha uma tendência para recuperar os nomes tradicionais e autóctones, juntamente com nomes "portugueses", para afirmar a característica própria desta nova geração - e de um modo de entender a decisão oficial quanto à consagração do tétum e do português como línguas oficiais da jovem nação (mas esta é uma história que necessita de outra ocasião para poder ser desenvolvida...). 
Anexo 1

Nomes próprios nos registos de baptismo de Dare, 1995

\begin{tabular}{|c|c|c|c|c|c|c|}
\hline Abel & 1 & António & 12 & Casimiro & l & Epifânio \\
\hline Abelita & 1 & Apilunário & I & Celélia & 1 & Ermelinda \\
\hline Abrão & 1 & Apolónia & I & Celestino & 3 & Ersilia \\
\hline Abril & 2 & Arcanjo & 3 & Celma & 2 & Esmeralda \\
\hline Adão & 6 & Armanda & 1 & Cesaltina & 2 & Esperansa \\
\hline Adelaide & 1 & Armando & 1 & César & I & Estanislau \\
\hline Adelina & 1 & Armindo & 2 & Cidália & 1 & Estélio \\
\hline Adelino & 1 & Arnaldo & 1 & Cipriano & 1 & Estelita \\
\hline Adélio & 1 & Arsénio & l & Clementino & 3 & Ester \\
\hline Adriano & 3 & Asnin & I & Cleofas & 1 & Eufrásia \\
\hline Adrianus & 1 & Atanásia & $\mathrm{l}$ & Constâncio & 1 & Eugénia \\
\hline Agapito & 1 & Atanásio & 1 & Constantino & 2 & Eugénio \\
\hline Agostinha & 3 & Augusta & 5 & Cornélio & 2 & Eulália \\
\hline Agostinho & 8 & Augusto & 3 & Crispim & l & Eva \\
\hline Agripina & 1 & Aurélia & 2 & Damaceno & 1 & Evalina \\
\hline Alberto & 4 & Áureo & $\mathrm{l}$ & Daniel & 4 & Evaristo \\
\hline Alcino & 2 & Aurora & I & Delfina & 2 & Ezequiel \\
\hline Alda & 2 & Auxiliadora & 1 & Deócia & 1 & Fabriana \\
\hline Aldikar & 1 & Baptista & l & Deolinda & 2 & Fátima \\
\hline Aleixo & 1 & Basílio & 1 & Didimos & 1 & Faustina \\
\hline Alfian & 1 & Beatriz & I & Diliana & I & Faustino \\
\hline Alfonsos & 1 & Bebiana & I & Dionísia & 2 & Feliciana \\
\hline Aliansa & 2 & Bendita & 3 & Dionísio & 2 & Feliciano \\
\hline Álvaro & 1 & Benjamim & I & Dirce & 1 & Felicidade \\
\hline Alzira & 2 & Benvindo & I & Dirson & 1 & Felisberta \\
\hline Amélia & 1 & Berkinta & I & Domingas & 10 & Felismina \\
\hline Amelita & 2 & Bernard & 1 & Domingos & 13 & Félix \\
\hline Amos & 1 & Bernardete & 1 & Dovêncio & l & Felizarda \\
\hline Ana & 6 & Bernardo & 3 & Duarte & 1 & Felizito \\
\hline Anabela & 1 & Berta & I & Dulce & 3 & Fenícia \\
\hline Anacleto & 2 & Bertalina & I & Ediana & 2 & Fernanda \\
\hline Anastásia & 1 & Bonfácio & I & Elfina & 1 & Fernando \\
\hline Andias & 1 & Bosco & 2 & Elias & 4 & Fidélio \\
\hline André & 1 & Calisto & l & Elisa & 4 & Filomena \\
\hline Ângela & 2 & Carla & 2 & Elisabete & 2 & Filomeno \\
\hline Angélica & 2 & Carlito & I & Elsa & 2 & Finantje \\
\hline Angelina & 7 & Carlos & 2 & Elvina & l & Flaviana \\
\hline Angelita & 2 & Carmelita & 4 & Elvira & 3 & Flaviano \\
\hline Angelito & 1 & Cármen & I & Elvis & 1 & Florêncio \\
\hline Aníbal & 1 & Carmenesa & 1 & Emília & I & Floriana \\
\hline Anita & 2 & Carolina & 3 & Emiliana & l & Floriano \\
\hline Antonino & 1 & Carrascalão & 1 & Emilita & 1 & Florida \\
\hline
\end{tabular}




\begin{tabular}{|c|c|c|c|c|c|c|}
\hline Florindo & 1 & Jacinta & 3 & Leoneto & 3 & Mecias \\
\hline Francelina & 1 & Jacinto & 2 & Leovigildo & 1 & Melano \\
\hline Francelino & l & Jacob & 2 & Letícia & 1 & Melina \\
\hline Francisca & 2 & Jaime & 2 & Lídia & 4 & Mércia \\
\hline Francisco & 7 & Jaimito & 3 & Lisinha & l & Metiliana \\
\hline Frederico & l & Januar & 6 & Lourença & 1 & Miguel \\
\hline Frediana & 1 & Jelito & l & Lourenço & 3 & Miguela \\
\hline Fulgêncio & 1 & Jeremias & 3 & Lucas & 2 & Miranda \\
\hline Gabriel & 6 & Jerónimo & 3 & Lúcia & 4 & Moisés \\
\hline Gabriela & 4 & Joana & 4 & Luciana & 2 & Mónica \\
\hline Gaspar & 1 & Joaninha & 8 & Luciano & 3 & Natália \\
\hline Geralda & 1 & Joanita & l & Lucília & 1 & Natalina \\
\hline Geraldo & I & João & 11 & Lucinda & 1 & Natalino \\
\hline Germano & 2 & Joaquina & 3 & Luís & 4 & Natércia \\
\hline Gerson & I & Joel & 3 & Luísa & 2 & Nazario \\
\hline Gertrudes & 1 & Johannes & 1 & Lurdes & 6 & Nélia \\
\hline Gil & 3 & Jonas & 1 & Lusitânia & 1 & Nelita \\
\hline Graciele & 1 & Jónia & 4 & Luzia & 1 & Nelito \\
\hline Guido & 1 & Jonito & 1 & Madalena & 9 & Nelson \\
\hline Guilherme & 3 & Jórdio & I & Mamilita & 1 & Nely \\
\hline \multirow{2}{*}{$\begin{array}{l}\text { Guilher- } \\
\text { mina }\end{array}$} & \multirow[b]{2}{*}{ l } & José & 16 & Manecas & 1 & Nicodemos \\
\hline & & Josef & 1 & Manuel & 4 & Nicolau \\
\hline Gustária & I & Josefa & 3 & Manuela & 1 & Nineti \\
\hline Hélder & I & Joséfias & 1 & Marcelina & 4 & Noé \\
\hline Helena & 2 & Josefina & 4 & Marcelino & 2 & Noélia \\
\hline Hendra & I & Jovâncio & l & Marcelo & 1 & Noémia \\
\hline Henrique & 2 & Jovita & l & Márcia & 1 & Nolasco \\
\hline \multirow{2}{*}{ Herculano } & \multirow[t]{2}{*}{1} & Judite & l & Marciana & 1 & Norberto \\
\hline & & Júlia & 1 & Marciano & 1 & Nova \\
\hline \multirow{2}{*}{$\begin{array}{l}\text { Hermene- } \\
\text { gildo }\end{array}$} & \multirow[t]{2}{*}{1} & Juliana & 5 & Marcos & 3 & Octaviano \\
\hline & & Julião & 1 & Margarida & 2 & Octávio \\
\hline Hermínia & 1 & Júlio & 9 & Maria & 28 & Ofélia \\
\hline Horácio & 1 & Julnavia & 1 & Mariana & 5 & Olandina \\
\hline Imaculada & 6 & Júnior & 1 & Mariano & 2 & Olaris \\
\hline Imelda & 3 & Juvenal & l & Marianus & 1 & Oldrico \\
\hline Inácio & 4 & Lamberto & 1 & Mariazinha & 3 & Olga \\
\hline Inês & 2 & Laura & 2 & Mário & 4 & Olinda \\
\hline Irevino & l & Laurentina & 1 & Marsal & 1 & Onémia \\
\hline Irineu & I & Laurentino & I & Marta & 3 & Orlando \\
\hline Isaac & 4 & Lauriana & 1 & Martinha & 1 & Óscar \\
\hline Isabel & 10 & Laurinda & 1 & Martinho & 6 & Osto \\
\hline Isaura & l & Leão & 1 & Martins & 1 & Oswaldo \\
\hline Ismael & l & Leonardo & 2 & Martinus & 1 & Otofina \\
\hline Iva & l & Leôncia & 1 & Mateus & 2 & Pascoela \\
\hline Ivone & l & Leôncio & 1 & Matias & 1 & Paulina \\
\hline
\end{tabular}




\begin{tabular}{ll|ll|ll|ll} 
Paulino & 1 & Romiro & 1 & Sebastião & 2 & Vasco & 3 \\
Paulo & 5 & Romualdo & 1 & Sejónia & 1 & Venâncio & 1 \\
Pedro & 5 & Rosa & 4 & Selviana & 1 & Verónica & 4 \\
Poitnawuno & 1 & Rosália & 1 & Sérgio & 2 & Vicário & 1 \\
Ponciano & 2 & Rosalina & 1 & Serurzinha & 1 & Vicarte & 3 \\
Quintão & 2 & Rosalino & 4 & Sezanino & 1 & Viegas & 1 \\
Quintina & 1 & Rosário & 1 & Ś́lvia & 1 & Violante & 1 \\
Rafael & 1 & Rosélia & 1 & Silviano & 1 & Virgília & 2 \\
Raimundo & 2 & Rosiana & 1 & Simão & 1 & Virgílio & 1 \\
Raquela & 1 & Rosita & 1 & Simião & 2 & Virgínia & 4 \\
Reinaldo & 2 & Rotário & 1 & Sisnan & 1 & Visentius & 1 \\
Remington & 1 & Ruben & 1 & Sofia & 2 & Vítor & 1 \\
Rianto & 1 & Rui & 2 & Solãngio & 1 & Vitorino & 1 \\
Ricardina & 1 & Rulisónia & 1 & Susana & 1 & Viviana & 1 \\
Ricardo & 2 & Salomão & 1 & Téfilo & 1 & Zacarias & 4 \\
Ricki & 1 & Salvador & 1 & Terêncio & 1 & Zeca & 2 \\
Rita & 2 & Samuel & 3 & Teresa & 3 & Zeferino & 3 \\
Robi & 1 & Sandra & 2 & Teresinha & 5 & Zélia & 4 \\
Rofina & 1 & Santiago & 2 & Tiago & 1 & Zelita & 1 \\
Rogério & 1 & Sara & 2 & Tobias & 1 & Zulmira & 3 \\
Rohadi & 1 & Saturnina & 1 & Tomé & 3 & Zuqueu & 1 \\
Romário & 1 & Sebastiana & 1 & Valéria & 1 & & \\
& & & & & & &
\end{tabular}

Fonte: Registos Paroquiais da Freguesia de Dare. 


\section{BIBLIOGRAFIA}

Alleton, Viviane, 1993, Les Chinois et la Passion des Noms. Paris, Aubier.

ALMEIDA, António de, 1994, O Oriente de Expressão Portuguesa. Lisboa, Fundação Oriente e Centro de Estudos Orientais.

ANDERSON, Benedict, 1992, Imagined Communities - Reflections on the Origins and Spread of Nationalism, Londres e Nova Iorque, Verso (edição revista).

BETHENCOURT, Francisco, e Kirti Chaudhuri (direcção), 1999, História da Expansão Portuguesa. Lisboa, Círculo de Leitores.

BUESCU, Maria Leonor, 1983, O estudo das Línguas Exóticas no Século XVI. Lisboa, ICLP.

CARDOSO, Luís, 1997, Crónica de uma Travessia. Lisboa, Publicações Dom Quixote.

CAREY, Peter, 1995, "Introdução histórica", em Cox e Carey, op. cit., pp. 9-55.

CARVALHO, Maria José Albarran, 2001, "Panorama linguístico de Timor - identidade regional, nacional e pessoal”, Camões, 14, pp. 67-79.

— , s/d, “Timor Lorosa'e e direcções desviantes do Português conservado/incompletamente adquirido na zona - contributos para a aprendizagem da língua oficial”, policopiado.

CINATTI, Ruy, 1996, Um Cancioneiro para Timor. Lisboa, Presença.

Constituição da República Democrática de Timor-Leste. Díli, Assembleia Constituinte, 2002.

CORreiA, Capitão Armando Pinto, 1944, Timor de Lés a Lés. Lisboa, Agência Geral das Colónias.

COSTA, Leão da, 2003, "A luta pela preservação da identidade cultural timorense no tempo da ocupação", em Estudos de Linguas e Culturas Timorenses, 5, pp. 11-17.

COSTA, Luís, 2001, Dicionário de Tétum-Português. Lisboa (2. a edição) Edições Colibri/Instituto Camões.

COX, Steve, e Peter Carey, 1995, Timor-Leste - Gerações de Resistência. Lisboa, Caminho.

De ROEVER, Arend, 1998, “The partition of Timor. An historical background", em Schouten, 1998, pp. 45-55.

DURAND, Frédéric, 2004, Catholicisme et Protestantisme dans l'île de Timor: 1556-2003. Construction d'une identité chretienne et engagement politique contemporain. Toulouse/Banguecoque, Editions Arkuiris/IRASEC.

—, 2002, Timor Lorosa'e. Pays au Carrefour de l'Asie et du Pacifique. Un Atlas Géo-Historique. Marne-la-Valée, Presses Universitaires de Marne-la-Valée.

EÇA DE QUeIROZ, José Maria, s.d. [1890], "A Campanha Alegre”, em Obras de Eça de Queiroz, vol. III. Porto, Lello e Irmão.

FACULDADE DE ARQUiTECTURA DE LISBOA et al., 2002, Atlas de Timor-Leste. Lisboa, Lidel.

FEIJÓ, Rui, 1987, “Um exercício sobre nomes”, Boletin de la Asociacion de Demografia Histórica, V/1, pp. 50-63.

GARTON ASH, Timothy, 2004, Free World. Londres, Penguin.

GINZBURG, Carlo, 1989, A Micro-História e Outros Ensaios. Lisboa, Difel.

GUNN, Geoffrey C., 1999, Timor LoroSae - 500 Years. Macau, Livros do Oriente.

HULL, Geoffrey, 2001, "Língua, identidade, resistência” (entrevista), Camões, 14, pp. 80-92. KOHEN, Arnold S., 2001, "The Catholic Church and the independence of East Timor," em Tanter et al. (eds.), 2001, pp. 43-51.

MATTOSO, José, 2005a, A Dignidade. Konis Santana e a Resistência Timorense. Lisboa, Temas e Debates. 
MATTOSO, José, 2005b “O arquivo da resistência e a unidade nacional”, em Resistência Timorense, 2005, pp. 11-14.

— 2003 , "Os arquivos e a cultura num país novo", Estudos de Línguas e Culturas de Timor-Leste, 5, pp. 1-10.

OWEN, Nornam G. (ed), 2005, The Emergence of Modern Southeast Asia - A New History. Honolulu, University of Hawai Press.

PINA CABRAL, João de, e Susana de Matos Viegas, 2007, Nomes, Género, Etnicidade e Família. Lisboa e São Paulo, Almedina.

RESISTÊNCIA TIMORENSE - ARQUIVO \& MUSEU, 2005, Catálogo, Díli.

RUAK, Taur Matan, 2001, "A importância da língua portuguesa na resistência contra a ocupação indonésia", Camões, 14, pp. 41-42.

SCHOUTEN, Maria Johanna (org.), 1998, A Ásia do Sudeste - História, Cultura e Desenvolvimento. Lisboa, Vega.

SUBrahmanyAM, Sanjay, 1995, O Império Asiático Portugês 1500-1700 - Uma História Política e Económica. Lisboa, Difel.

TANTER, Richard, Mark Selden, e Stephen R. Shalom (eds.), 2001, Bitter Flowers, Sweet Flowers - East Timor, Indonesia and the World Community. Sydney, Pluto Press Australia.

ThOMAZ, Luís Filipe Reis, 2002, Babel Loro Sa'e - O Problema Linguístico de Timor-Leste. Lisboa, Instituto Camões.

—_, 1994, De Ceuta a Timor. Lisboa, Difel.

WILSON, Stephen, 1997, The Means of Naming - A Social and Cultural History of Personal naming in Western Europe. Londres, UCL Press.

Language, name and identity in competitive plurilingualism: the case of East-Timor - Rui Graça Feijó • ruifeijo@gmail.com

This essay discusses the interplay between language, name and identity in the plurilingual context of East-Timor. Namely, I will approach the relationships between given and family name as one of the distinctive characters of the Timorese linguistic system. Through names and naming practices in East-Timor, and the way they are construed and articulated with other contemporary phenomena, I will discuss the different levels of cultural identity and the bases that support the configuration and sense of Timorese national identity.

KEYWORDS: East-Timor, naming, plurilingualism, identity. 